\title{
CLINICOPATHOLOGICAL PROFILE OF GASTROINTESTINAL TUBERCULOSIS PATIENTS AT A TERTIARY CARE HOSPITAL
}

\author{
Prasann K. Bandi', Kamal Malukani², Prashant S. Yeshwante ${ }^{3}$, Shirish S. Nandedkar ${ }^{4}$, Ashok Rajoreya ${ }^{5}$, Gaurav Khare ${ }^{6}$
}

1 Professor, Department of Pathology, Sri Aurobindo Medical College and Post Graduate Institute.

${ }^{2}$ Associate Professor, Department of Pathology, Sri Aurobindo Medical College and Post Graduate Institute.

${ }^{3}$ Post Graduate Resident, Department of Pathology, Sri Aurobindo Medical College and Post Graduate Institute.

${ }^{4}$ Professor, Department of Pathology, Sri Aurobindo Medical College and Post Graduate Institute.

${ }_{5}^{5}$ Post Graduate Resident, Department of Pathology, Sri Aurobindo Medical College and Post Graduate Institute.

${ }^{6}$ Post Graduate Resident, Department of Pathology, Sri Aurobindo Medical College and Post Graduate Institute.

ABSTRACT

\section{BACKGROUND}

Abdominal tuberculosis represents the sixth most frequent form of extra-pulmonary tuberculosis after lymphatic, genitourinary, bone and joint, miliary and meningeal tuberculosis. It can affect gastrointestinal, lymphatic and pancreatobiliary system.

\section{AIMS}

To study clinicopathological features of biopsies and resected abdominal specimens diagnosed as TB.

\section{METHODS AND MATERIAL}

It is a cross-sectional study and include 135 patients diagnosed histopathologically as GITB between January 2004 to June 2015 in a Tertiary Health Care Centre. Analysis of various intestinal tuberculous lesions in relation to age, gender, socioeconomic class, clinical signs and symptoms, basic hematological parameters, histopathological findings etc. was done.

\section{RESULTS}

Out of total 135 cases, $75(55.56 \%)$ were males and 60(44.44\%) were females with male:female ratio being 1.25:1. Maximum incidence of GITB was seen in 21-30 years age group. Maximum number of GITB cases belonged to low (Lower and upper lower) socio-economic class, i.e. $58.52 \%$. Abdominal pain (95.56\%) was the most common presenting symptom and abdominal tenderness $(67.41 \%)$ was most common clinical sign. Ileo-caecal junction $(38.52 \%)$ was the most common site involved in GITB. AFB positivity in tissue was reported in $16.3 \%$ cases out of total 135 GITB cases.

\section{CONCLUSION}

The diagnosis of GITB is difficult and careful approach to the patients and supportive investigation data are necessary to make the final diagnosis. Neither clinical features nor laboratory findings are conclusive of GITB, histopathological findings by themselves provide a gold standard in the diagnosis.

\section{KEYWORDS}

Gastrointestinal Tuberculosis, Abdominal Tuberculosis, Intestinal Lesions, Tuberculosis.

HOW TO CITE THIS ARTICLE: Prasann K. Bandi, Kamal Malukani, Prashant S. Yeshwante, Shirish S. Nandedkar, Ashok Rajoreya, Gaurav Khare. "Clinicopathological Profile of Gastrointestinal Tuberculosis Patients at a Tertiary Care Hospital." Journal of Evolution of Medical and Dental Sciences 2015; Vol. 4, Issue 102, December 21; Page: 16730-16735,

DOI: $10.14260 /$ jemds/2015/2504

\section{INTRODUCTION}

Tuberculosis detected as far back as $10000 \mathrm{BC}$, still remain a major public health problem worldwide. ${ }^{1}$ it ranks as the second leading cause of death from an infectious disease worldwide, after the Human Immunodeficiency Virus (HIV). ${ }^{2}$ hence called as "The Captain of all men of death." According to World Health Organization (WHO), worldwide there were 9.6 million new TB cases in 2014 and 1.5 million TB deaths (1.1 million among HIV-negative people and 0.4 million among HIV-positive people). India, Indonesia and China had the largest number of cases $(23 \%, 10 \%$ and $10 \%$ of the global total respectively). ${ }^{3}$ TB mortality is unacceptably high given that most deaths are preventable if people can access health care for a diagnosis and the correct treatment is provided. Abdominal tuberculosis represents the sixth most frequent form of extra-pulmonary tuberculosis after lymphatic, genitourinary, bone and joint, miliary and meningeal tuberculosis. ${ }^{4}$

Financial or Other, Competing Interest: None.

Submission 23-11-2015, Peer Review 24-11-2015,

Acceptance 14-12-2015, Published 18-12-2015.

Corresponding Author:

Dr. Kamal Malukani,

601, Akansha Apartment,

Sri Aurobindo Hospital Campus, Indore, Madhya Pradesh

E-mail: kamal.malukani@yahoo.com

DOI:10.14260/jemds/2015/2504
Abdominal TB accounts for $2 \%$ of all cases of tuberculosis. ${ }^{5}$ and about $12 \%$ of extrapulmonary TB. ${ }^{6}$ It can affect gastrointestinal, lymphatic and pancreaticobiliary system. ${ }^{7}$ Most of the cases of Gastrointestinal Tuberculosis (GITB) are due to M. tuberculosis. M. bovis earlier accounted for a substantial number of cases worldwide, is now less frequently encountered due to widespread pasteurization of milk. Clinical manifestations of GITB are often non-specific and to be confused with many other diseases, specially Crohn's disease, intestinal neoplasms, amoebiasis and yersinia infection. ${ }^{8}$

Laboratory and radiological findings are also nonconclusive. There is no single feature, which is diagnostic for GITB. A combination of symptomatology and diagnostic tools is used, but histopathology still remains the gold standard for the diagnosis of GITB in routine practice. Many cases of GITB present with complications due to delayed diagnosis. The associated mortality and morbidity demand prospective research to find out the ways and procedure to reduce this.

The present study aims at a fresh look into GITB and a better understanding of its clinical manifestations and histopathological diagnosis. 


\section{AIMS AND OBJECTIVES}

The objectives of present study are:

- To study the demographic factors associated with Gastrointestinal Tract Tuberculosis (GITB) like age, sex and socioeconomic status.

- To find out the common organ and site of involvement in cases of GITB.

- To study clinical and hematological findings in cases of GITB.

- To study gross and microscopic features of biopsies and resected abdominal specimens diagnosed as TB.

- To apply Ziehl Neelsen stain and find out incidence of Acid Fast Bacilli (AFB) positivity in cases of GITB.

\section{MATERIAL AND METHODS}

It is a cross-sectional study and include 135 patients diagnosed histopathologically as GITB between January 2004 to June 2015 in a Tertiary Health Care Centre.

\section{Inclusion Criteria}

- All patients diagnosed histopathologically as GITB on biopsies/resected surgical specimens.

\section{Exclusion Criteria}

- All clinically suspected TB patients, but not diagnosed as TB on histopathological examination of biopsies/resected surgical specimens were excluded from the study.

- Autolysed specimens.

- Visceral form of abdominal TB involving solid organs (Liver, Spleen and Pancreas) without definitive involvement of GI tract.

A detailed information including age, gender, history of pulmonary TB, socioeconomic status, history of contact with TB patient's, etc. clinical signs and symptoms, basic hematological parameters were recorded in the proforma.

For retrospective cases, slides and paraffin blocks of previously diagnosed cases of GITB were retrieved from Surgical Pathology Department and reviewed. Additional sections were cut to prepare fresh slides wherever required, stained and studied.

For prospective cases, all biopsies and resected surgical specimens of GIT clinically suspected as TB were received in $10 \%$ neutral buffered formalin in the Department of Surgical Pathology. The details of gross examination findings of biopsies and resected specimens were noted. Tissues were processed, sections were cut by microtome and evaluated after staining by Haematoxylin and Eosin technique. Zeihl Neelson staining was done to demonstrate Acid fast Bacilli.

We selected one of the following two criteria for the diagnosis of GITB in present study:

1. Histological demonstration of characteristic epithelioid granulomas with or without caseation either in the biopsies/resected bowel or regional lymph nodes.

2. Demonstration of acid fast bacilli in the Zeihl Neelson sections of biopsies/resected bowel or regional lymph nodes.

Analysis of various intestinal tuberculous lesions in relation to age, gender, socioeconomic class, clinical signs and symptoms, basic hematological parameters, histopathological findings, etc. was done.

\section{RESULTS}

Out of total 135 cases, $75(55.56 \%)$ were males and $60(44.44 \%)$ were females with male:female ratio being 1.25:1. Maximum incidence of GITB was seen in 21-30 years age group in females and 31-40 years age group in males. Overall, maximum incidence (28.89\%) of GITB was seen in 21-30 years age group. Youngest patient in the present study was of 2 years while oldest one was of 78 years (Mean age 32.97 years). Table
1 shows age and gender-wise distribution of GITB cases. Maximum number of GITB cases belonged to low (Lower and upper lower) socio-economic class, i.e. $58.52 \%$. Middle socioeconomic class constitute $39.26 \%$ and Upper socio-economic class constitute only $2.22 \%$ of total 135 cases.

Abdominal pain (95.56\%) was the most common presenting symptom followed by anorexia (74.81\%) and altered bowel habits (65.92\%). Cough was present in 31.85\% of total cases, although past history of pulmonary tuberculosis was given by 84 patients $(62.22 \%)$. Table 2 shows common presenting symptoms of GITB reported in the present study.

Abdominal tenderness (67.41\%), cachexia (65.92\%) and pallor $(62.22 \%)$ were common clinical signs. Table 3 shows various clinical signs reported in GITB cases in present study. Laboratory investigations revealed low haematocrit (Less than $41 \%$ in male and less than $36 \%$ in female) in $73.33 \%$ cases of GITB, but haemoglobin (Hb) was low in only $34.07 \%$ of cases. Leucocytosis with lymphocytosis was seen in $38.52 \%$ and monocytosis in $33.33 \%$ of GITB cases. Erythrocyte Sedimentation Rate (ESR) was raised (more than $30 \mathrm{~mm}$ at the end of first hour) in $57.78 \%$ of GITB cases. Mantoux test was positive (More than $10 \mathrm{~mm}$ of induration and erythema) in $71.85 \%$ cases of GITB. Acid Fast Bacilli (AFB) were detected in sputum in $26.21 \%$ cases out of 103 GITB cases; $4.44 \%$ cases of GITB were reactive for Human Immunodeficiency Virus (HIV) Ileo-caecal junction (38.52\%) was the most common site involved in GITB cases followed by ileum (35.56\%), caecum (9.63\%), colon (5.92\%), appendix (5.18\%), rectum/anal canal (2.96\%), jejunum $(1.48 \%)$ and stomach $(0.74 \%)$.

Most common finding on gross examination of resected specimens was ulcer (81\%) followed by strictures (49.42\%), band and adhesions (20.74\%), perforation (17.78\%), hypertrophic mass (15.55\%), tubercles over surface $(9.63 \%)$ and ulcero-hypertrophic lesion (8.15\%). Table 4 shows macroscopic findings of GITB cases. Most common finding on microscopic examination was tuberculous granuloma (97.03\%) followed by Langhan's type giant cells (95.56\%), caseous necrosis $(79.26 \%)$ and foreign body giant cells $(15.56 \%)$. AFB positivity in tissue was reported in $16.3 \%$ cases out of total 135 GITB cases.

\section{DISCUSSION}

When the results of the present study are analyzed against the backdrop of the available literature, many results are concordant with the previous studies, but few disparities are also noticeable.

\section{Age-Wise Distribution of GITB Cases}

In the present study, maximum incidence of GITB was seen in 21-30 years age group followed by 31-40 years (25.18\%). These results are consistent with the findings of Darbari A et al. ${ }^{2}$ (58\%), Krishnanand et al. ${ }^{9}$ (54.8\%), Tripathi PB et al. ${ }^{10}$ (55.4\%), Zea MI et al. ${ }^{11}$ (64\%), Saaiq M et al.12 (61.37\%), Shimy GG et al. ${ }^{13}$ (45.56\%), Islam MB et al. ${ }^{14}(75 \%)$ and Rabbi ANMA et al. ${ }^{15}(54.54 \%)$.

Abdominal tuberculosis like tuberculosis elsewhere in the body affects the young people at the peak of their productive life. This fact has serious impact on the national economy and production, as working and productive class of community is replaced by sick and ill individuals.

\section{Gender Wise Distribution of GITB Cases}

In the present study out of total 135 cases, $55.56 \%$ were males and $44.44 \%$ were females with M:F ratio being 1.25: 1 . Sharma YR et al. ${ }^{16}$ (2.57:1), Darbari A et al. $^{2}$ (1.3:1) and Shimy GG et al. ${ }^{13}(\mathrm{M}: \mathrm{F}=1.25: 1)$ have reported male preponderance in GITB cases. On the contrary, Lal V et al. ${ }^{17}$ ( $\left.\mathrm{M}: \mathrm{F}=1: 1.38\right)$,

Sankpal J et al. ${ }^{18}(\mathrm{M}: \mathrm{F}=1: 1.6)$ and Shrestha $\mathrm{S}$ et al. ${ }^{19}$ (M:F $=1: 2.2$ ) have reported female preponderance in their studies. 
Tripathi PB et al. ${ }^{10}$ have reported equal incidence of GITB in both gender. So conclusion cannot be drawn and we can say that GITB can affect both genders without any predilection. Differences may be due to geographical variation and catchment of health services.

\section{Socio-Economic Class}

Various authors have reported GITB cases in low socioeconomic class ranging from $60 \%$ (Islam MB et al. ${ }^{14}$ ) to $83 \%$ (Niaz K et al. ${ }^{20}$ ) We have reported $58.52 \%$ of GITB cases belonging to low socioeconomic class in our study. As undernutrition, unhygienic environment and overcrowding are commonly associated with low socio-economic class, this may be the reason of maximum incidence of GITB in this class.

\section{Clinical Presentation}

Abdominal pain was the most common presenting symptom reported by most of the previous authors. It ranged from $51.2 \%$ (Uygur Bayramicli 0 et al. ${ }^{21}$ ) to $100 \%$ (Shimy GG et al. ${ }^{13}$ Lal $\mathrm{V}$ et al. ${ }^{17}$ Sankpal J et al. ${ }^{18}$ ) of GITB cases in various studies. Abdominal pain in GITB may be due to intestinal obstruction, perforation or peritonitis. Similarly altered bowel habits in GITB are due to intestinal ulcers, strictures and subacute obstruction.

Association of Pulmonary Tuberculosis (PTB) with GITB cases as reported by various authors ranges from $8.91 \%$ (Sankpal J et al. ${ }^{18}$ ) to $50 \%$ (Tripathi PB et al. ${ }^{10}$ ) in previous studies. In the present series, association of PTB was reported in $34.81 \%$ of GITB cases. Abdominal tenderness (67.41\%) was found as most common clinical sign in the present study, which is consistent with the studies of Sharma YR et al.16 $(48 \%)$ Ibrahim M et al. ${ }^{22}$ (74\%), Shimy GG et al. ${ }^{13}$ (81.1\%) and Lal V et al. ${ }^{17}(64 \%)$. Abdominal tenderness may be due to intestinal obstruction, perforation or peritonitis.

In the present study intestinal obstruction was reported in $47.41 \%$ of total 135 GITB cases. Previous authors have reported intestinal obstruction ranging from 9.3\% (Ibrahim et al. ${ }^{22}$ ) to $66.65 \%$ (Krishnanand et al. ${ }^{9}$ ). Intestinal obstruction occurs mainly due to narrowing of the lumen by hyperplastic caecal tuberculosis by strictures of the small intestine, which are commonly multiple or by adhesions. Various authors have reported peritonitis ranging from $6 \%$ (Darbari et al. ${ }^{2}$ ) to $35.7 \%$ (Shimy GG et al. ${ }^{13}$ ) in their studies. In present study, we found signs of peritonitis in $17.78 \%$ of 135 GITB cases. Acute tubercular peritonitis may be due to perforation. Acute tubercular peritonitis without perforation is usually an acute manifestation of peritoneal disease, but may be due to ruptured caseating lymph nodes.

\section{Laboratory Investigations}

In the present study, anaemia was reported in $73.33 \%$ of total 135 cases. Various authors have reported anaemia ranging from $30 \%$ (Darbari A et al. $^{2}$ ) to $77.36 \%$ (Miah AR et al. ${ }^{23}$ ) in previous studies. Anaemia in abdominal tuberculosis may be due to nutritional deficiency as malabsorption is commonly associated with subacute intestinal obstruction. Malabsorption is due to bacterial overgrowth and bile salt deconjugation in the upper small intestine.

ESR was raised in $57.78 \%$ of GITB cases in the present study. Previous authors have reported raised ESR in $46 \%$ (Ibrahim M et al. ${ }^{22}$ ) to $90 \%$ (Shreshtha $\mathrm{S}$ et al. ${ }^{19}$ ) of GITB cases.

As Mantoux test is a non-specific test, reported positive in $19.2 \%$ (Uygur Bayramicli 0 et al. ${ }^{21}$ ) to $85.57 \%$ (Islam MB et al. ${ }^{14}$ ) cases by various authors in their studies; $71.85 \%$ cases have positive Mantoux test in the present study. Negative Mantoux test may be due to GI loss of protein and anorexia leading to hypoalbuminemia.

\section{Anatomic sites Involved in GITB}

Ileocaecal junction was the most common site involved in GITB cases in the present study, which is in concordant with the studies done by Sharma YR et al. ${ }^{16}(28 \%)$, Islam MB et al. ${ }^{14}$ (51.6\%), Ibrahim $\mathrm{M}$ et al. ${ }^{22}$ (38.46\%), Tripathi PB et al.10 (50.9\%), Rabbi ANMA et al. ${ }^{15}$ (56.52\%) and Zea MI et al. ${ }^{11}$ $(72.22 \%)$. The exact explanation for more frequent involvement of the ileocaecal region is unknown, but it may be due to a variety of factors such as increased rate of fluid/electrolyte absorption, abundance of lymphoid tissue in the form of Peyer's patches, physiological stasis and minimal digestive activity at the ileocaecal region.

In the present study, mesenteric lymphadenopathy was reported in $31.11 \%$ of total 135 GITB cases. Zea MI et al. ${ }^{11}$ reported mesenteric lymph node involvement in all $(100 \%)$ cases. Tripathi PB et al. ${ }^{10}$ reported in $65.5 \%$ cases, Islam MB et al. ${ }^{14}$ in $53.3 \%$ cases, Lal V et al. ${ }^{17}$ in $48 \%$ cases, Shrestha $\mathrm{S}$ et al. ${ }^{19}$ in $18.7 \%$ cases, Uygur-Bayramicli 0 et al. ${ }^{21}$ in $16.8 \%$ cases, Ibrahim $M$ et al. ${ }^{22}$ in $12 \%$ cases, Saaiq $M$ et al. ${ }^{12}$ in $11.58 \%$ cases, Sankpal J et al. ${ }^{18}$ in $10.45 \%$ cases and Sharma YR et al. ${ }^{16}$ in $8 \%$ cases.

\section{Macroscopic Findings}

Ileo-caecal TB is conventionally classified into ulcerative, ulcero-hypertrophic and hypertrophic lesion.

Malik AK et al. ${ }^{24}$ (77.5\%), Tripathi PB et al. ${ }^{10}$ (66.4\%) and Lal $\mathrm{V}$ et al. $^{17}(60 \%)$ have reported ulcerative lesion in maximum cases of GITB. Even in the present study, ulcerative lesion was reported in maximum cases (60\%) of GITB. Ulcer in GITB is transverse to the long axis of ileum. Hypertrophic mass reported in GITB cases by various authors ranged from $2.5 \%$ (Malik AR et al. ${ }^{24}$ ) to $48.3 \%$ (Islam MB et al. ${ }^{14}$ ). In the present study, hypertrophic mass (15.55\%) was reported as a second most common finding, while it was reported as a most common finding in the study by Islam MB et al. ${ }^{14}$ It occurs due to fibrotic thickening of intestinal wall and sometimes it may mimic malignancy.

In the present study, band and adhesions were reported in $20.74 \%$ of total 135 GITB cases, which is in concordance with the studies of Sankpal J et al. ${ }^{18}$ (22.39\% cases), Jamal S et al. ${ }^{25}$ (22.73\% cases) and Saaiq M et al. ${ }^{12}$ (23.78\% cases).

Tubercles over the serosal surface were reported in $7.46 \%$ (Sankpal J et al. ${ }^{18}$ ) to $70 \%$ (Islam MB et al. ${ }^{14}$ ) cases by various authors in their studies. In the present study tubercles were reported in $9.63 \%$ of GITB cases. Tubercles in GITB are due to secondary involvement of intestine by hematogenous spread of mycobacteria.

Strictures were seen in 16\% (Darbari A et al. ${ }^{2}$ ) to $69.5 \%$ (Saaiq $\mathrm{M}$ et al.12) cases by various authors in their studies. In the present study, strictures were reported in $49.62 \%$ cases, which is in concordance studies of Arbo A et al. ${ }^{26}$ in $46.7 \%$ cases and Lal $\mathrm{V}$ et al. ${ }^{17}$ in $42 \%$ cases. In the present study, in few cases multiple strictures were reported. And in few cases combination of perforation with strictures and perforation with bands/adhesions were also reported. The chronic inflammation of TB is a transmural inflammation and heals by fibrosis resulting in strictures.

Authors have reported perforation in GITB cases ranging from 3.3\% (Islam MB et al. ${ }^{14}$ ) to $68.2 \%$ (Jamal S et al. ${ }^{25}$ ) cases. In the present study perforation in GITB cases was reported in $44.44 \%$ cases. Tuberculosis is the second common cause of perforation after typhoid. Perforation may be near strictures due to obstruction. An increased incidence of perforation has also been observed with HIV infection, low immunity and failed antitubercular therapy. Perforation in GITB is usually found in ileum and rarely at any other sites. In the present study caecal perforation was reported in 4 cases of GITB, which is unusual site. 


\section{Microscopic Findings}

Tuberculous granuloma, the most common microscopic finding in cases of GITB reported by various authors ranged from $67.5 \%$ to $100 \%$ cases. Vij JC et al. ${ }^{27}$ have reported tuberculous granulomas in $67.5 \%$ cases, Ibrahim $\mathrm{M}$ et al. ${ }^{22}$ in $84 \%$ cases, Sharma YR et al. ${ }^{16}$ in $92.86 \%$ cases, Chao $\mathrm{CH}$ et al. ${ }^{28}$ in $95 \%$ cases and Malik AK et al. ${ }^{24}$ Tripathi PB et al. ${ }^{10}$ and Lal V et al. ${ }^{17}$ reported in $100 \%$ cases. In the present study, tuberculous granulomas were reported in $97.03 \%$ of total 135 GITB cases. Though the hallmark of diagnosing GITB is demonstration of caseating granulomas on histologic examination, non-caseating granulomas may be seen in some cases due to low virulence of the organism or high resistance of the host or due to previous anti-tubercular therapy.

In the present study, four (2.96\%) out of total 135 GITB cases, tubercular granulomas were present in the mesenteric lymph nodes and absent in intestinal lesions.

Langhan's type giant cells were reported by various authors ranged from $55 \%$ to $95.56 \%$ cases in their studies. Malik AK et al. ${ }^{24}$ have reported Langhan's type giant cells in $55 \%$ cases, Vij JC et al. ${ }^{27}$ in $67.5 \%$ cases and Chao $\mathrm{CH}$ et al. ${ }^{28}$ in $80 \%$ cases. Langhan's type giant cells were reported in $95.56 \%$ cases of GITB in the present study. Various authors have reported caseous necrosis in their studies ranged from $13.51 \%$ to $92.86 \%$ cases. Vij JC et al. ${ }^{27}$ have reported caseous necrosis in $13.51 \%$ cases, Lal V et al. ${ }^{17}$ in $59 \%$ cases, Tripathi PB et al. ${ }^{10}$ in $61.8 \%$ cases, Chao CH et al. ${ }^{28}$ in $75 \%$ cases, Malik AK et al. ${ }^{24}$ in $80 \%$ cases and Sharma YR et al. ${ }^{16}$ in $92.86 \%$ cases. In the present study, caseous necrosis was reported in $79.26 \%$ of total 135 GITB cases. Foreign body giant cells in GITB cases were reported by Malik AK et al. ${ }^{24}$ in $17.5 \%$ cases in their study, while in the present study it was reported in $15.56 \%$ of total 135 GITB cases.

\section{CONCLUSION}

To conclude, our study showed that GITB is commonly seen in young males of lower socioeconomic status with ileocaecal junction being most common anatomical site involved. Patients of GITB most commonly presents with abdominal pain \& tenderness may be associated with altered bowel habits and cachexia although varied mode of clinical presentation has been reported. History of pulmonary tuberculosis and cough may or may not be associated. Most patients of GITB are anaemic with high Erythrocyte Sedimentation Rate (ESR) mostly associated with lymphocytosis and monocytosis. Ulcerative lesions are most commonly seen in resected specimens of GITB. Histologically presence of caseating tuberculous granulomas is the gold standard for diagnosis of GITB as acid fast bacilli are detected in very few cases.

The diagnosis of GITB is difficult and careful approach to the patients and supportive investigation data are necessary to make the final diagnosis. Neither clinical features nor laboratory findings are conclusive of GITB, histopathological findings by themselves provide a gold standard in the diagnosis.

\section{REFERENCES}

1. Larry I Lutwick. Tuberculosis, a clinical handbook, $1^{\text {st }}$ ed. London u.a.: Chapman and Hall Medical; 1995.

2. Darbari A, Jauhari A, Darbari G, Shrivastava V, Shrivastava A. Abdominal tuberculosis: a study of 50 cases. Int J Res Med Sci 2014; 2:1453-61.

3. World Health Organization. Global tuberculosis report 2015. Geneva: WHO. Aug 2015. Available from URL: apps.who.int/iris/bitstream/10665/191102/1/ 9789241565059_eng.pdf.
4. WHO. Global tuberculosis control 2012. [Internet]: World Health Organization. (Online) (Cited 2011 April 11). Available from URL:

http://www.who.int/tb/publications/global_report/en/i ndex.html.

5. Kishore PV, Chandresekher TS, Palaian S. Diagnosing Abdominal Tuberculosis: A retrospective study from Nepal. The Internet Journal of Gastroenterology 2007;6.

6. Sheer TA, Coyle WJ. Gastrointestinal tuberculosis. Curr Gastroenterol Rep 2003;5:273-8.

7. Sharma D, Gupta A, Jain BK, Agrawal V, Dargan P, Upreti L, et al. Tuberculous Gastric Perforation: report of a case. Surg today 2004;34:537-41.

8. Hulnick DH, Megibow AJ, Naidich DP, Hilton S, Cho KC, Balthazar EJ. Abdominal tuberculosis: CT evaluation. Radiology 1985;157:199-204.

9. Krishnanand, Chanchlani R, Chanchlani M, et al. A Study of Clinical Presentation and Management of Abdominal Tuberculosis in a Tertiary Care Hospital. Journal of Evolution of Medical and Dental Sciences 2013;46:892531.

10. Tripathi P, Amarapurkar AD. Morphological spectrum of gastrointestinal tuberculosis. Trop Gastroenterol 2009;30:35-9.

11. Zea MI, Farooqui R, Ahsan MM, et al. Prospective study of changing pattern of occurrence and treatment of abdominal tuberculosis at JNMC Aligarh over a period of six years. Indian J Sci Res 2014;9:47-50.

12. Saaiq M, Shah SA, Zubair M. Abdominal Tuberculosis: Epidemiologic Profile and Management Experience of 233 cases. J Pak Med Assoc 2012;62:704-7.

13. Shimy GG, Borham MM and MB Gaber M. Incidence of Tuberculosis In Acute Abdomen In Endemic Area. Al-Azhar Assiut Medical Journal 2013;11.

14. Islam MB, Rahman MK, Islam MK, et al. Clinicopathological Study of Intestinal Tuberculosis and its Management. TA] 2003;16:24-7.

15. Rabbi ANMA, Jahan FAJ, Aziz MM. Abdominal Tuberculosis. KYAMC Journal. 2010;1:16-20.

16. Sharma YR. Abdominal tuberculosis - a study of 25 cases. Kathmandu University Medical Journal 2003;2:137-41.

17. Lal V, Deolekar S, Mahapatra B, et al. Study of gastrointestinal tuberculosis and role of surgery in its management in Navi Mumbai: analysis of 50 cases. Indian Journal of Basic and Applied Medical Research 2014;4:363-74.

18. Sankpal J, Shetty S, Sankpal M, Tilwani V, Nikale V, Hatkar A. Clinical study of Abdominal Tuberculosis. International Journal of Scientific and Engineering Research, 2014;5:543.

19. Shrestha S, Pradhan GB, Bhoomi K, et al. Abdominal Tuberculosis in Nepal Medical College Teaching Hospital, Kathmandu. Saarc J Tuber Lung Dis HIV/AIDS 2008;5. DOI: http://dx.doi.org/10.3126/saarctb.v5i1.3083.

20. Niaz K, Ashraf M. Intestinal tuberculosis: Diagnostic dilemma. Professional Med J 2010;17:532-7.

21. Uygur-Bayramicli O, Dabak G, Dabak R. A clinical dilemma; abdominal tuberculosis. World J Gastroenterol 2003;9:1098-101.

22. Ibrahim M, Osoba A0. Abdominal Tuberculosis: On-going challenge to gastroenterologists. Saudi Med J 2005;26:27480.

23. Miah AR, Sharma YR, Rahman MT, Raihan A, Roy PK, Hasan M. Clinicopathological profile of patients with abdominal tuberculosis. J Nepal Health Res Counc 2011;9:16975.Malik AK, Pal L, Wig JD. Histomorphological Spectrum of Gastrointestinal Tuberculosis. Bahrain Medical Bulletin 2004;26:1-7. 
24. Jamal S, Khan ZM, Ahmed I, et al. Presentation and outcome of Abdominal Tuberculosis in a Tertiary Care Unit. Ann Pak Inst Med Sci 2011;7:33-6.

25. Arbo A, Siddiqui FG, Akhtar S, et al. Spectrum of Clinical Presentation and Surgical Management of Intestinal Tuberculosis at Tertiary Care Hospital. J Ayub Med Coll Abbottabad 2010;22:96-9.

\begin{tabular}{|c|c|c|c|c|c|}
\hline \multirow{2}{*}{$\begin{array}{l}\text { Sl. } \\
\text { No. }\end{array}$} & \multirow{2}{*}{$\begin{array}{l}\text { Age } \\
\text { Group }\end{array}$} & \multicolumn{4}{|c|}{ No. of Cases } \\
\hline & & Male & Female & Total & $\begin{array}{l}\text { Percent } \\
\text { age }\end{array}$ \\
\hline 1 & $0-10$ & 5 & 1 & 6 & 4.44 \\
\hline 2 & $11-20$ & 10 & 12 & 22 & 16.29 \\
\hline 3 & $21-30$ & 15 & 24 & 39 & 28.89 \\
\hline 4 & $31-40$ & 19 & 15 & 34 & 25.18 \\
\hline 5 & $41-50$ & 9 & 3 & 12 & 8.89 \\
\hline 6 & $51-60$ & 11 & 3 & 14 & 10.37 \\
\hline 7 & $61-70$ & 5 & 1 & 6 & 4.44 \\
\hline 8 & $71-80$ & 1 & 1 & 2 & 1.48 \\
\hline \multicolumn{2}{|c|}{ Total } & $\begin{array}{c}75 \\
(55.56 \\
\%)\end{array}$ & $\begin{array}{c}60 \\
(44.44 \\
\%)\end{array}$ & $\begin{array}{c}135 \\
(100 \\
\%)\end{array}$ & 100 \\
\hline \multicolumn{6}{|c|}{$\begin{array}{l}\text { Table 1: Age and Gender-wise } \\
\text { distribution of GITB cases }\end{array}$} \\
\hline
\end{tabular}

\begin{tabular}{|c|c|c|c|}
\hline Sl. No. & Symptoms & No. of Cases & Percentage \\
\hline 1 & Abdominal pain & 129 & 95.56 \\
\hline 2 & Fever & 84 & 62.22 \\
\hline 3 & Weight Loss & 89 & 65.92 \\
\hline 4 & Anorexia & 101 & 74.81 \\
\hline 5 & Nausea/Vomiting & 73 & 54.07 \\
\hline 6 & $\begin{array}{c}\text { Altered bowel } \\
\text { habits }\end{array}$ & 89 & 65.92 \\
\hline 7 & Melena & 04 & 2.96 \\
\hline 8 & Night sweats & 31 & 22.96 \\
\hline 9 & $\begin{array}{c}\text { Abdominal } \\
\text { Distension }\end{array}$ & 87 & 64.44 \\
\hline 10 & Abdominal Lump & 12 & 8.89 \\
\hline 11 & \multicolumn{4}{|c|}{ Cough } & 43 & 31.85 \\
\hline \multicolumn{4}{|c|}{ Table 2: Common presenting } \\
\hline \multicolumn{4}{|c|}{ symptoms reported in GITB cases } \\
\hline
\end{tabular}

\begin{tabular}{|c|c|c|c|}
\hline $\begin{array}{c}\text { Sl. } \\
\text { No }\end{array}$ & Sign & $\begin{array}{c}\text { No. of } \\
\text { Cases }\end{array}$ & Percentage \\
\hline 1 & $\begin{array}{c}\text { Abdominal } \\
\text { tenderness }\end{array}$ & 91 & 67.41 \\
\hline 2 & Abdominal Mass & 32 & 23.70 \\
\hline 3 & Ascites & 52 & 38.52 \\
\hline 4 & Cachexia & 89 & 65.92 \\
\hline 5 & Hepatomegaly & 15 & 11.11 \\
\hline 6 & Splenomegaly & 06 & 4.44 \\
\hline 7 & $\begin{array}{c}\text { Intestinal } \\
\text { Obstruction }\end{array}$ & 64 & 47.41 \\
\hline 8 & Pallor & 84 & 62.22 \\
\hline 9 & Oedema & 10 & 7.40 \\
\hline 10 & Peritonitis & 24 & 17.78 \\
\hline Tables
\end{tabular}

Table 3: Common Clinical Signs Reported In GITB Cases
26. Vij JC, Malhotra V, Choudhary V, Jain NK, Prasad G, Choudhary A, et al. A Clinicopathological Study of Abdominal Tuberculosis. Ind J Tub 1992;39:213-20.

27. Chou CH, Ho MW, Ho CM, Lin PC, Weng CY, Chen TC, et al. J Microbiol Immunol Infect 2010;43:395-400.

\begin{tabular}{|c|c|c|c|}
\hline $\begin{array}{l}\text { Sl. } \\
\text { No. }\end{array}$ & $\begin{array}{l}\text { Macroscopic } \\
\text { Findings }\end{array}$ & $\begin{array}{l}\text { No. of } \\
\text { Cases }\end{array}$ & $\%$ \\
\hline 1 & Ulcer & 81 & 60 \\
\hline 2 & $\begin{array}{l}\text { Ulcero- } \\
\text { hypertrophic lesion }\end{array}$ & 11 & 8.15 \\
\hline 3 & $\begin{array}{l}\text { Hypertrophic } \\
\text { (mass) lesion }\end{array}$ & 21 & 15.55 \\
\hline 4 & Bands \& Adhesions & 28 & 20.74 \\
\hline 5 & $\begin{array}{l}\text { Tubercles over } \\
\text { surface }\end{array}$ & 13 & 9.63 \\
\hline 6 & Strictures & 67 & 49.62 \\
\hline 7 & Perforation & 24 & 17.78 \\
\hline \multicolumn{4}{|c|}{$\begin{array}{l}\text { Table 4: Macroscopic findings observed } \\
\text { in resected specimens of GITB }\end{array}$} \\
\hline
\end{tabular}

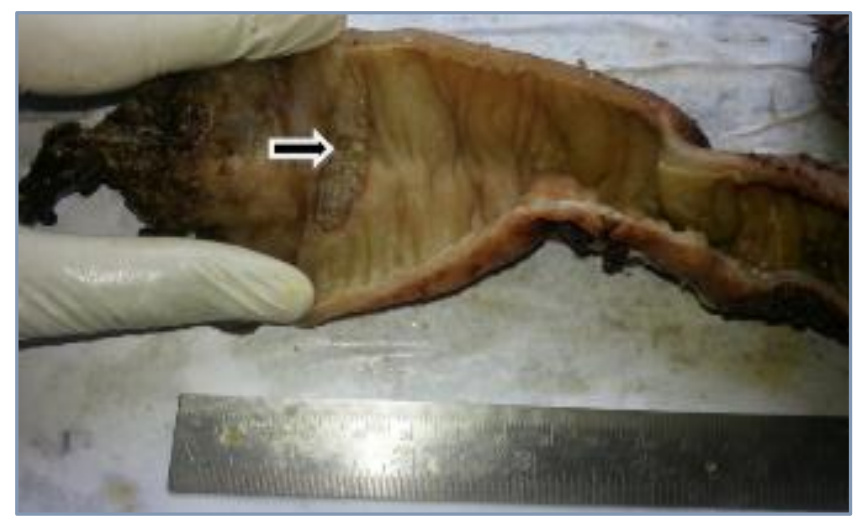

Fig. 1: Photograph showing transverse ulcer ( $\uparrow$ ) in mucosa of small intestine

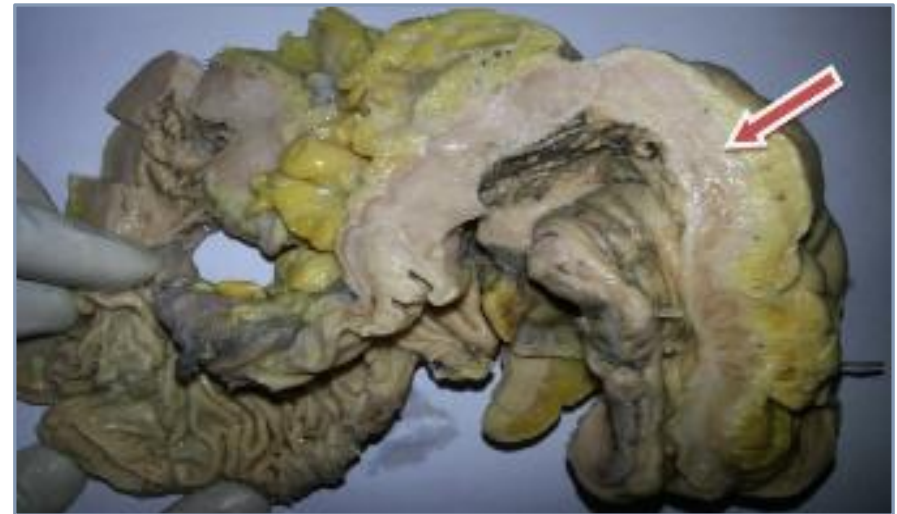

Fig. 2: Photograph showing thickened caecal wall ( $\uparrow$ ) in a case of hyperplastic tuberculosis 


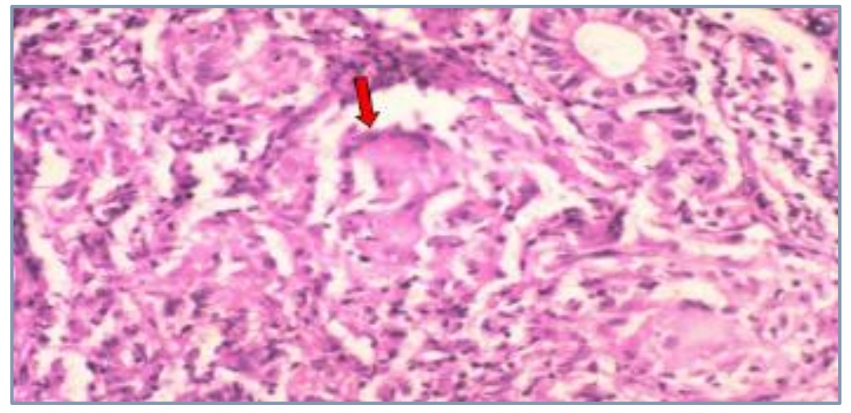

Fig. 3: Microphotograph showing gastric gland ( $\uparrow$ ) and epithelioid granuloma with Langhan's type of giant cell (1). (H\&E, 400X)

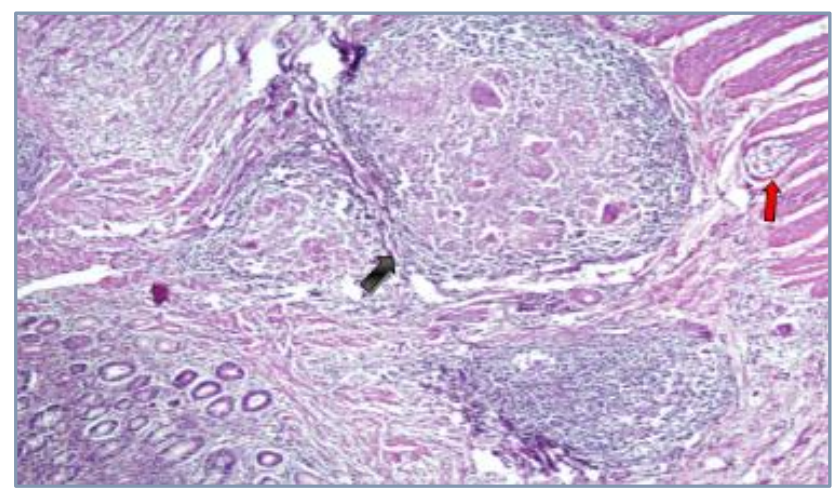

Fig. 4: Microphotograph showing ileal wall with chronic inflammatory cell infiltrate and caseating epithelioid granulomas in submucosa ( $\uparrow$ ) and muscle layer (1). (H\&E, 40X)

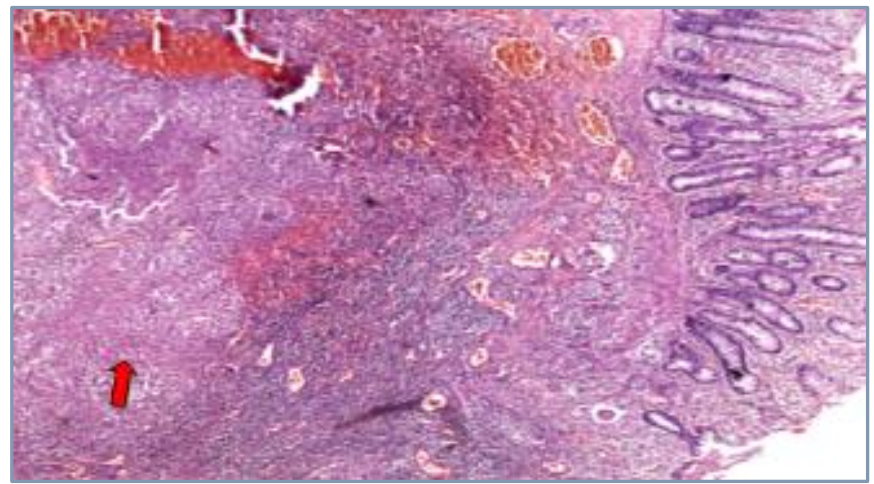

Fig. 5: Microphotograph of colon showing caseous necrosis in the submucosa with congested blood vessels and epithelioid cell granulomas (\). (H\&E, 40X)

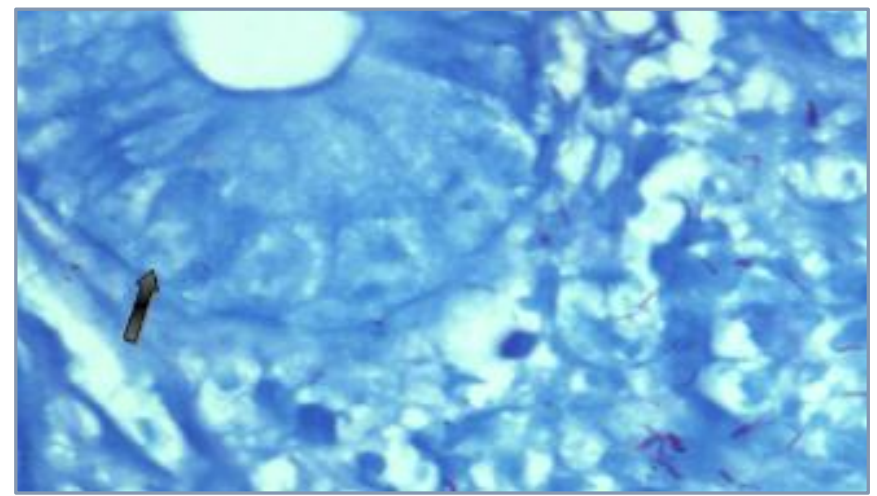

Fig. 6: Microphotograph showing multiple beaded acid fast bacilli and mucous gland $(\uparrow)$ in a section of ileum. 